\title{
PENERAPAN KURIKULUM MENGACU KKNI DAN IMPLIKASINYA TERHADAP KUALITAS PENDIDIKAN DI PTKIN
}

\author{
Any Umy Mashlahah \\ IAIN Kudus, Jawa Tengah, Indonesia \\ uumbahtiar@gmail.com
}

\begin{abstract}
The purpose of this paper is to find out how the application of the curriculum refers to KKNI and its implications for improving the quality of PTKIN education. The research method with literature study is packaged descriptively based on theoretical analysis. The results of this study are: (1) the application of curriculum refers to KKNI through several stages: compiling learning achievements, formulating the profile of graduates of study programs, formulation of competency standards for learning outcomes graduates, formulation of learning outcomes of study programs (learning outcomes/PLO programs), formulation of learning outcomes courses (leaning outcomes/CLO), identify key concepts and keywords in the achievement of course learning, RPKPS development; (2) improving the quality of PTKIN is influenced by the application/ application of curriculum referring to KKNI through three main factors namely: (a) the adequacy of educational resources in terms of the quality of teaching staff, costs and learning facilities; (b) the quality of teaching and learning processes that encourage students to learn effectively; (3) the quality of output in the form of knowledge, attitudes, and skills.
\end{abstract}

Keywords: Curriculum, KKNI, Education Quality, PTKIN. 


\begin{abstract}
Abstrak
Tujuan penulisan ini adalah untuk mengetahui bagaimana penerapan kurikulum mengacu KKNI dan implikasinya terhadap peningkatan kualitas pendidikan PTKIN. Metode penelitian dengan studi literatur yang dikemas secara deskriptif berdasarkan analisis teoretis. Hasil penelitian ini adalah: (1) penerapan kurikulum mengacu KKNI melalui beberapa tahapan: menyusun capaian pembelajaran, merumuskan merumuskan profil lulusan program studi, perumusan standar kompetensi lulusan learning outcomes, perumusan capaian pembelajaran program studi (program learning outcomes/PLO), perumusan capaian pembelajaran mata kuliah (course leaning outcomes/CLO), mengenali konsep kunci dan kata kunci pada capaian pembelajaran mata kuliah, pengembangan RPKPS; (2) peningkatan kualitas PTKIN depengaruhi penerapan/penerapan kurikulum mengacu KKNI melalui tiga faktor utama, yaitu: (a) kecukupan sumber-sumber pendidikan dalam arti kualitas tenaga kependidikan, biaya dan sarana belajar; (b) kualitas proses belajar-mengajar yang mendorong siswa belajar efektif; (3) kualitas keluaran dalam bentuk pengetahuan, sikap, dan keterampilan.
\end{abstract}

Kata Kunci: Kurikulum, KKNI, Kualitas Pendidikan, PTKIN.

\title{
A. Pendahuluan
}

World Trade Organisation (WTO) atau organisasi perdagangan dunia menjadi tantangan besar bagi dunia pendidikan menyongsong tahun 2020. Lulusan lembaga pendidikan nasional dituntut mampu bersaing di dunia internasional. Implikasinya menjadi sebuah urgensi bagi setiap lembaga pendidikan dalam negeri, terutama perguruan tinggi, untuk meluluskan sumber daya manusia Indonesia yang berkualitas setara luar negeri. Setiawan (2016: 349) berpendapat bahwa kualitas sumber daya manusia di Indonesia memang menjadi isu sentral di dalam lingkungan lembaga pendidikan sejak beberapa dekade terakhir. Khusus untuk jenjang perguruan tinggi, pemerintah telah mengeluarkan Indonesian Qualification Frame Work atau Kerangka Kulifikasi Nasional Indonesia (KKNI) sebagaimana diatur dalam Peraturan Presiden No. 8 Tahun 2012 sebagai pernyataan kualitas sumber daya manusia Indonesia yang perjenjangan kualifikasinya didasarkan pada tingkat kemampuan yang dinyatakan dalam 
rumusan capaian pembelajaran (learning outcomes). Perguruan tinggi sebagai penghasil sumber daya manusia terdidik perlu mengukur kelulusannya agar sesuai dengan capaian pembelajaran yang telah dirumuskan dalam jenjang kualifikasi KKNI dan standar kompetensi yang ditetapkan.

Selama ini, masyarakat mengukur kehebatan lembaga pendidikan dari aspek keterserapan dunia kerja; semakin banyak lulusan memenuhi lapangan kerja, semakin sebuah lembaga pendidikan dianggap berkualitas. Ukuran ini terkadang tidak match dengan lembaga pendidikan dengan program studi yang memang tidak terkait langsung dengan lapangan kerja. Program studi ilmu sosial dan ilmu agama, misalnya, tidak bisa diukur kualitasnya semata-mata berdasarkan keterserapan lulusannya pada lapangan kerja. Jadi, ukuran kualitas yang dapat menjadi barometer lulusan ilmu-ilmu keagamaan yang bernaung di bawah Pendidikan Tinggi Keagamaan Islam Negeri (PTKIN) dalam pandangan yang lebih komprehensif sepertinya belum ada (Syam, 2014: 12).

Berkenaan dengan kualitas, ada beberapa persoalan yang perlu menjadi catatan dalam tulisan ini. Pertama, tantangan kelembagaan dan kualitas kualitas lembaga. PTKIN sebagai bagian dari lembaga pendidikan dalam percaturan kehidupan global haruslah menyikapi era globalisasi ini dengan sebaik-baiknya. Jika PTKIN ingin memainkan perannya dalam masyarakat global, tidak dapat tidak, PTKIN haruslah melebarkan sayapnya ke bidang sains dan tekhnologi tanpa memisahkannya dari nilainilai agama yang suci. Hal ini penting dilakukan untuk melahirkan generasi yang punya daya saing tinggi dan berkarakter. Tantangan yang dihadapi adalah terbatasnya kewenangan yang dimiliki oleh PTKIN dalam mengembangkan program studi atau jurusan. Akibatnya, akses ke perguruan tinggi oleh generasi muda sangat terbatas. Peningkatan status dari STAIN ke IAIN atau dari IAIN ke UIN tanpa diiringi dengan pembukaan program studi baru strategis tentu tidak banyak memberikan arti. Kedua, PTKIN juga harus menghadapi tantangan politik anggaran. Secara umum, tantangan dalam pembangunan dan pengembangan PTKIN adalah masih rendahnya anggaran pendidikan di PTKIN yang notabene 
berada di lingkungan Kementerian Agama dibandingkan dengan PTN yang berada di bawah Kementerian Riset dan Pendidikan Tinggi. Agar PTKIN dapat maju dan bersaing di kancah global sebagai World University, salah satu faktor yang perlu manjadi pertimbangan adalah politik anggaran yang berpihak kepada pendidikan. Walaupun dalam lingkungan Kementerian Agama telah ditanamkan nilai luhur untuk mendedikasikan diri dalam dunia pendidikan melalui moto "Ikhlas Beramal”, faktor pendanaan tidak bisa dikesampingkan. Paling tidak, ke depan perhatian dalam melengkapi fasilitas pendidikan lebih ditingkatkan. Ketiga, tantangan yang dihadapi PTKIN adalah menyangkut political will. Walaupun berbagai teori dan fakta membuktikan tentang hebatnya kontribusi PTKIN dalam mempersiapkan generasi bangsa yang bersaing dan berkarakter, kurangnya komitmen yang kuat dan nyata dari politisi dalam bentuk kebijakan penganggaran yang proporsional bagi PTKIN membuat kontribusi tidak maksimal. Karena itu, komitmen dari politisi yang membidangi anggaran sangat perlu ditingkatkan.

Bagi PTKIN sendiri, pelaksanaan Undang-Undang No. 12 Tahun 2012 Tentang Pendidikan Tinggi (UU Dikti) akan terasa sangat menyulitkan ditinjau dari sudut minat. Seandainya minat masyarakat masuk ke PTKIN itu sama dengan animo masyarakat untuk masuk ke UI, ITB, Unair, IPB, UGM, atau PTN besar lainnya yang memang memanggul ilmu duniawi, mungkin saja kerisauan itu tidaklah sedemikian kuat. Akan tetapi, dengan kenyataan bahwa minat untuk studi Islamic Studies yang memang sedari semula kecil, yang dikhawatirkan adalah ketidakmampuan PTKIN untuk meng-arrange anggaran yang relatif besar sebagai konsekuensi memasuki penerapan UU Dikti. Bagi perguruan tinggi yang sudah menjadi BHMN (Badan Hukum Milik Negara) juga memperoleh manfaat yang besar terkait dengan generate income-nya. Misalnya UI yang sebelum menjadi PT BHMN hanya memperoleh anggaran sebesar Rp 200 miliar, setelah menjadi PT BHMN penghasilannya meningkat menjadi Rp 800 miliar. Demikian pula UGM yang meraup dana sebesar Rp 600 miliar. Di sisi lain, otonomisasi dan kemandirian bagi PTN yang bertujuan agar PTN mampu memobilisasi dana dari masyarakat yang juga 
merupakan buah dari UU Dikti, menjadikan PTKIN pontangpanting dalam mencari dana untuk pengelolaan penyelenggaraan pendidikan di institusinya. Satu di antaranya disebabkan jumlah peminat untuk memasuki PTKIN relatif terbatas, kemudian kemampuan untuk mengakses anggaran dari masyarakat juga sangat terbatas. Padahal, menjadi perguruan tinggi berbadan hukum tersebut identik dengan kemandirian dan otonomi kelembagaan pendidikan tinggi yang secara kelembagaan harus memperoleh anggaran secara mandiri (Effendi, 2007: 1).

Pantaslah kemudian jika dikatakan kebijakan politik pemerintah hingga saat ini masih terasa sebagai politik belah bambu: menginjak yang bawah dan mengangkat setinggitingginya kalangan atas. Hal tersebut membuat PTKIN memiliki kendala dalam menyiapkan dan menghasilkan lulusan yang berkualitas sesuai dengan standar pendidikan. Dengan demikian, perluasan kewenangan serta peningkatan kualitas lembaga dan politik anggaran yang berpihak pada kemajuan pendidikan perlu menjadi perhatian agar apa yang diharapkan oleh PTKIN, yakni menyiapkan lahirnya generasi yang memiliki kemampuan tinggi di bidangnya, mampu bersaing di tingkat global, serta memiliki karakter yang kuat dan lulusan yang berkualitas dapat diwujudkan.

Berdasarkan argumentasi di atas, dapat dipahami secara sederhana bahwa penerapan kurikulum yang berkualitas akan melahirkan lulusan yang berkualitas pula, pun sebaliknya. Namun, dalam fenomena yang penulis amati, masih banyak pelaku kurikulum di pendidikan tinggi, terutama dosen, yang belum menerapkan keempat komponen kurikulum tersebut secara holistik sehingga tidak heran jika terjadi kepincangan pembelajaran yang sangat berpengaruh terhadap kualitas lulusan. Selaras dengan perkembangan ilmu pengetahuan, teknologi dan seni serta tuntutan ke depan yang makin kompleks, diperlukan suatu sistem kurikulum yang adaptif dan antisipatif terhadap tuntutan zaman, serta mudah diterapkan dalam praksis kependidikan. Kebijakan KKNI ini tentu harus dikelola sedemian rupa, sehingga proses penjaminan kualitas lulusan lembaga pendidikan dapat dipertanggungjawabkan. Pada PTKIN, tingkat 
penerapan kurikulum mengacu pada KKNI masih beragam. Sebagian PTKIN baru pada taraf penyusunan Kurikulum KKNI melalui workshop pada tingkat fakultas dan pascasarjana. Berdasarkan uraian tersebut, penulis tertarik mengkaji pengaruh penerapan kurikulum mengacu KKNI terhadap peningkatan kualitas pendidikan PTKIN.

Adapaun rumusan permasalahan dalam tulisan ini adalah: (1) bagaimana penerapan kurikulum mengacu KKNI pada PTKIN? (2) apakah terdapat pengaruh penerapan kurikulum mengacu KKNI terhadap peningkatan kualitas pendidikan PTKIN? Sesuai dengan rumusan masalah tersebut, tujuan dalam penulisan ini adalah untuk mengetahui: (1) penerapan kurikulum mengacu KKNI pada PTKIN; (2) implikasi penerapan kurikulum mengacu KKNI terhadap peningkatan kualitas pendidikan di PTKIN.

\section{B. Pembahasan}

\section{Kurikulum Mengacu KKNI}

Kurikulum merupakan "jantung” institusi pendidikan atau sistem pembelajaran. Tanpa kurikulum proses pembelajaran menjadi tidak jelas arah dan orientasinya. Kurikulum (curriculum, al-manhaj), yang secara bahasa berarti jalan yang jelas, tidak hanya berupa struktur mata pelajaran dan silabus, melainkan keseluruhan pengetahuan, keterampilan, pengalaman, dan kepribadian yang akan ditransformasikan melalui proses pendidikan, sehingga peserta didik mengalami perkembangan dan kemajuan ke arah terbentuknya pribadi yang berpikir rasional, berpengetahuan luas, bersikap positif, berketerampilan, dan berkerpibadian sosial (al-Jabburi, 2013: 224).

Presiden Republik Indonesia telah mengeluarkan peraturan tentang Kerangka Kualifikasi Nasional Indonesia (KKNI) pada 17 Januari 2012 sebagai Peraturan Presiden Nomor 8 Tahun 2012, yang bertujuan memberikan arah tenaga kerja Indonesia. Pada Bab I Ketentuan Umum Peraturan Presiden tersebut menyebutkan bahwa yang dimaksud dengan mengacu KKNI ialah kerangka penjenjangan kualifikasi kompetensi yang dapat menyandingkan, menyetarakan dan mengintegrasikan antara bidang pendidikan 
dan bidang pelatihan kerja serta pengalaman kerja dalam rangka pemberian pengakuan kompetensi kerja sesuai dengan struktur pekerjaan di berbagai sektor.

Peraturan Presiden pada Bab II berbunyi bahwa KKNI terdiri dari 9 jenjang. Jenjang 1-3 dikelompokkan dalam jabatan operator. Jenjang 4-6 merupakan kelompok jabatan teknisi atau analis, sedangkan jenjang 7-9 adalah kelompok jabatan ahli. Setiap jenjang kualifikasi memiliki kesetaraan dengan capaian pembelajaran yang dihasilkan melalui pendidikan dan pelatihan kerja atau pengalaman kerja. Penyetaraan capaian pembelajaran dihasilkan melalui pendidikan dengan jenjang kualifikasi pada KKNI sebagaimana berikut: lulusan pendidikan dasar setara dengan jenjang 1 ; lulusan pendidikan menengah paling rendah setara dengan jenjang 2; lulusan diploma 1 paling rendah setara dengan jenjang 3 ; lulusan diploma 2 paling rendah setara dengan jenjang 4; lulusan diploma 3 paling rendah setara dengan jenjang 5; lulusan diploma 4 atau sarjana terapan dan sarjana paling rendah setara dengan jenjang 6; lulusan magister terapan dan magister paling rendah setara dengan jenjang 8 ; lulusan doktor terapan dan doktor setara dengan jenjang 9 .

Menurut Suwadi (2016: 12), KKNI memiliki beberapa persamaan dalam sistem sertifikasi dan penghargaan dengan kurikulum berbasis kompetensi (KBK) yang diberlakukan sebelumnya. Orang yang memiliki sertifikasi kompetensi memiliki standar penghargaan. Sertifikasi kompetensi dilakukan oleh lembaga sertifikasi atau pengguna. KKNI memiliki deskripsi generik yang menentukan kemampuan lulusan, apakah tingkat operator, teknisi/analis, atau jabatan ahli yang juga terkait dengan sistem penghargaan. KBK menggunakan istilah kompetensi, sedangkan KKNI menggunakan istilah capaian pembelajaran atau learning outcome (LO). Capaian pembelajaran adalah kemampuan yang diperoleh melalui internalisasi pengetahuan, sikap, keterampilan, kompetensi, dan akumulasi pengalaman kerja.

Lebih lanjut, Suwadi (2016: 14-15) menyatakan bahwa terbitnya Perpres No. 8 Tahun 2012 dan UU PT No. 12 Tahun 2012 Pasal 29 ayat (1), (2), dan (3) berdampak pada kurikulum dan pengelolaannya di setiap program. Kurikulum yang pada 
awalnya mengacu pada pencapaian kompetensi menjadi mengacu pada capaian pembelajaran (learning outcomes). Capaian pembelajaran (learning outcomes) merupakan internalisasi dan akumulasi ilmu pengetahuan, ketrampilan, sikap, dan kompetensi yang dicapai melalui proses pendidikan yang terstruktur dan mencakup suatu bidang ilmu/keahlian tertentu atau melalui pengalaman kerja. Secara ringkas, KKNI terdiri dari sembilan level kualifikasi akademik SDM Indonesia. Adanya KKNI ini diharapkan dapat mengubah cara melihat kompetensi seseorang: tidak lagi semata ijazah, tetapi juga melihat kerangka kualifikasi yang disepakati secara nasional sebagai dasar pengakuan terhadap hasil pendidikan seseorang secara luas (formal, nonformal, atau informal) yang akuntanbel dan transparan.

Selanjutnya, dalam Permendikbud Nomor 73 Tahun 2003 Tentang Penerapan Kurikulum KKNI Bidang Pendidikan Tinggi dinyatakan bahwa dalam menerapkan KKNI bidang pendidikan tinggi perguruan tinggi mempunyai tugas dan fungsi: (a) setiap program studi wajib menyusun deskripsi capaian pembelajaran minimal mengacu pada KKNI bidang bidang pendidikan sesuai dengan jenjang; (b) setiap program studi wajib menyusun kurikulum, melaksanakan, dan mengevaluasi pelaksanaan kurikulum mengacu pada KKNI bidang pendidikan tinggi dengan kebijakan, regulasi dan panduan tentang penyusunan kurikulum program studi.

Menurut Setiawan (2016: 351-352), penyusunan kurikulum mengacu KKNI pada dasarnya disusun sesuai prinsip yang berlaku dalam prinsip-prinsip penyelarasan KKNI. Penyelasan merupakan upaya penyesuaian pendidikan sebagai pemasok SDM dengan dunia kerja yang memiliki kebutuhan dan tuntutan yang dinamis. Konsep penyelarasan mengisyaratkan adanya kebutuhan koordinasi yang baik antara pihak penyedia lulusan pendidikan. Analisis kebutuhan dunia kerja yang meliputi kualitas/kompetensi dan kuantitas pada lokasi dan waktu yang berbeda merupakan informasi awal yang perlu disediakan dalam proses penyelarasan. Informasi kebutuhan dunia kerja yang akurat dan rencana pengembangan nasional di berbagai sektor diperlukan dalam reengineering sistem pendidikan pada setiap level dan bidang 
dalam menyediakan SDM sesuai dengan kebutuhan dunia kerja. Reengineering seluruh aspek pendidikan seperti sarana prasarana, tenaga pendidik, sistem pembelajaran, harus ditujukan untuk pencapaian keselarasan antara pendidikan dan dunia kerja. Upaya penyelarasan yang optimal melalui penerapan rangkaian program yang sistematis dan berkesinambungan memerlukan adanya rasa memiliki dan keterlibatan semua pemangku kepentingan termasuk masyarakat pada umumnya.

Suwito, dkk. (2016: 13-18) dalam Laporan Review Kurikulum Mengacu KKNI dan SNPT menguraikan penerapan kurikulum mengacu KKNI melalui beberapa tahapan, yaitu menyusun capaian pembelajaran, merumuskan profil lulusan program studi, perumusan standar kompetensi lulusan learning outcomes, perumusan capaian pembelajaran program studi (program learning outcomes/PLO), perumusan capaian pembelajaran mata kuliah (course leaning outcomes/CLO), menemukenali konsep kunci dan kata kunci pada capaian pembelajaran mata kuliah, pengembangan RPKPS (Rencana Program dan Kegiatan Pembelajaran Semester), dengan rincian sebagai berikut.

Tahap pertama, menyusun capaian pembelajaran universitas (university lerning outcomes) yang diturunkan dari visi dan misi universitas yang mengandung profil umum lulusan sebagai competitive dan comparative advantange dari universitas tersebut. Capaian pembelajaran universitas lebih menampilkan soft skill dibandingkan hard skill yang harus dimiliki lulusan universitas tersebut.

Tahap kedua, merumuskan profil lulusan program studi. Profil lulusan adalah peran yang diharapkan dapat dilakukan oleh lulusan program studi di masyarakat/dunia kerja. Profil ini adalah outcome pendidikan yang akan dituju. Profil lulusan adalah jawaban atas pertanyaan: lulusan seperti apa yang akan dihasilkan oleh program studi setelah mereka menyelesaikan seluruh rangkaian pendidikannya (outcomes). Atau, "Setelah lulus nanti, akan menjadi apa saja lulusan program studi ini?” Profil ini bisa saja merupakan profesi tertentu misal dokter, pengacara, apoteker, dan lainnya, tetapi bisa juga sebuah peran tertentu seperti manajer, 
pendidik, peneliti, atau juga sebuah peran yang lebih umum yang sangat dibutuhkan di dalam banyak kondisi dan situasi kerja, seperti komunikator, kreator, pemimpin, dan sebagainya. Dalam rumusan profil, disarankan ditulis peran profesional dan serangkaian kompetensi (learning outcomes) yang harus dimiliki lulusan untuk menjalankan peran tersebut secara profesional, akuntabel, berakhlak mulia, memiliki pengetahuan, keterampilan, kemandirian, dan sikap untuk menemukan, mengembangkan, serta menerapkan ilmu, teknologi, dan seni, yang bermanfaat bagi kemanusiaan. (PP No. 19 Tahun 2005 Pasal 26 ayat (4)). Profil lulusan mengacu pada capaian pembelajaran universitas, agar terbentuk kesinambungan proses untuk mencapai visi dan misi universitas. Namun, kekhasan lulusan program studi menjadi bagian penting untuk menunjukkan keunggulan kompetitif (competitive advantage) dari setiap progam studi.

Tahap ketiga, perumusan standar kompetensi lulusan. Setelah menetapkan profil lulusan program studi sebagai outcome pendidikan, langkah selanjutnya adalah menentukan kompetensi apa saja yang harus dimiliki oleh lulusan program studi sebagai output pembelajarannya.

Tahap keempat, perumusan capaian pembelajaran program studi (program learning outcomes/PLO). PLO merupakan jabaran lengkap profil lulusan yang berkenaan dengan kompetensi apa yang harus dimiliki oleh mahasiswa setelah lulus program studi tertentu di perguruan tinggi. Learning outcomes (capaian pembelajaran) sedikitnya terdiri dari dua jenis kalimat yang menyatu, yaitu kata kerja (verb) yang menunjukkan tingkat kognitif (yang menunjukkan tingkat pengetahuan yang harus dikuasai) dan atau psikomotorik (keterampilan yang harus ditunjukkan), dan content knowledge atau kata benda (noun) yang menunjukkan tingkatan pengetahuan, yakni fakta, konsep, prosedural, dan metakognitif yang dilandasi oleh sikap (afektif) yang tepat dalam melakukan pekerjaan. Capaian pembelajaran program studi dirumuskan berdasarkan hasil tracer study (studi pelacakan) dan analisis kebutuhan dunia kerja yang terkait dengan kompetensi yang dibangun, serta jenjang kualifikasi yang diacu dari KKNI. Dengan memperhatikan deskriptor pada jenjang 5, 
6, 7, 8, dan 9 berikut, dapat ditemukenali tingkat kualifikasi dan kompetensi yang dibutuhkan lulusan program studi sesuai dengan stratanya.

Tahap kelima, perumusan capaian pembelajaran mata kuliah (course leaning outcomes/ CLO). CLO dengan jelas menggambarkan apa yang akan mahasiswa ketahui dan apa yang dapat dilakukan mahasiswa di akhir perkuliahan. Capaian pembelajaran perkuliahan mengacu kinerja (performance) dan berorientasi pada hasil. CLO merupakan gambaran yang bermakna (significant) dan terkait dengan apa yang diharapkan dapat dilakukan mahasiswa di "dunia nyata" pembelajaran yang "benarbenar penting dalam jangka panjang". CLO menggambarkan apa yang dapat dilakukan mahasiswa di akhir perkuliahan ketika mereka mengintegrasikan pembelajaran dari seluruh perkuliahan yang diperolehnya. Setiap CLO harus sejalan dengan satu atau lebih capaian pembelajaran program studi (PLO).

Tahap keenam, menemukenali konsep kunci dan kata kunci pada capaian pembelajaran mata kuliah. Pernyataan konsep kunci (key concept) tidak dimaksudkan hanya untuk concept knowledge pada ranah pengetahuan Bloom, tetapi juga ditekankan pada content knowledge dari setiap capaian pembelajaran mata kuliah. Konsep-konsep kunci sesungguhnya merupakan daftar dari konsep inti pada perumusan bidang kajian yang dimiliki program studi. Konsep-konsep inti ini pula yang dapat dijadikan patokan dalam menghitung beban kerja mahasiswa (student work load) yang menjadi dasar perhitungan jumlah kredit untuk setiap mata kuliah. Karena dalam setiap konsep kunci yang di dalamnya terdapat kata-kata kunci (key word), dapat diperkirakan waktu yang dibutuhkan untuk mencapai penguasaan konsep tersebut (time expectation). Pertanyaan yang dapat membantu menemukenali konsep kunci adalah konsep-konsep penting apa (essential concept) yang paling sedikit yang dikuasai mahasiswa untuk mencapai kompetensi yang diharapkan? Kandungan pengetahuan yang ada pada konsep kunci dapat dipetakan melalui tingkatan kognitif $(\mathrm{C} 1=1 ; \mathrm{C} 2=2 ; \mathrm{C} 3=3 ; \mathrm{C} 4=4 ; \mathrm{C} 5=5$; dan $\mathrm{C} 6=6$ ) dan ranah pengetahuan (factual knowledge, conceptual 
knowledge, procedural knowledge, dan metacognitive) dari Nloom yang telah direvisi oleh Kratwohl dan Anderson.

Tahap ketujuh, pengembangan RPKPS (Rencana Program dan Kegiatan Pembelajaran Semester). Mengadaptasi pendapat Clark dan Lampert (1986) dinyatakan bahwa perencanaan pembelajaran adalah determinan utama dari apa yang diajarkan. Kurikulum yang dipublikasikan, ditransformasikan, dan diadaptasikan dalam proses perencanaan dengan penambahan, penghapusan, interpretasi, dan keputusan dosen tentang kecepatan, urut-urutan, dan penekanan (pengajarannya). Dalam perencanaan pembelajaran termasuk di dalamnya mengalokasikan waktu pembelajaran untuk individu-individu dan kelompok-kelompok mahasiswa; menyusun kelompok-kelompok mahasiswa; mengorganisasikan jadwal harian, mingguan, dan triwulanan; dan mengompensasi waktu untuk interupsi di luar kelas dan berkomunikasi dengan dosen pengganti.

Ketujuh tahapan tersebut di atas apabila diterapkan dengan baik dalam pengembangan PTKIN, maka akan dapat meningkatkan kualitas PTKIN. Artinya, pengembangan kurikulum KKNI merupakan salah satu upaya pembaruan pendidikan yang telah disusun berdasarkan berbagai pertimbangan dan pendekatan, dimulai dari menyusun rasional, mengembangkan kerangka dasar, serta penyusunan pedoman pengelolaan kurikulum mengacu KKNI.

Dalam penerapan kurikulum mengacu KKNI terdapat beberapa fakta yang merisaukan, ketika standar kompetensi lulusan dalam negeri yang mengacu pada SKKNI dikomparasikan dengan standar kompetensi lulusan beberapa negara industri maju, ternyata terlihat perbedaan yang sangat mencolok. Di sisi lain, Pasal 8 Peraturan Presiden Tentang KKNI menyatakan pada Ayat (1) bahwa pengakuan dan penyetaraan kualifikasi pada KKNI dengan kerangka kualifikasi negara lain atau sebaliknya, baik secara bilateral maupun multilateral, dilakukan atas dasar perjanjian kerja sama saling pengakuan yang diatur sesuai dengan ketentuan peraturan perundang undangan. Ayat (2) menyatakan bahwa perjanjian kerja sama saling pengakuan sebagaimana dimaksud 
pada Ayat (1) diatur oleh lembaga yang berwenang mengeluarkan notifikasi dan perjanjian kerja sama saling pengakuan.

Dari Pasal 8 di atas, jelas salah satu upaya untuk mendekatkan diri dengan kualifikasi yang diterapkan dinegara lain adalah dengan cara membandingkan dan mempelajari apa yang telah kita lakukan dengan apa yang telah dilakukan oleh negara lain. Perbedaan yang sangat nyata adalah pada jabatan pekerjaan, deskripsi jabatan, pengetahuan yang harus dikuasai, keterampilan yang harus dimiliki, pengalaman kerja, dan kinerja dalam jabatan, bahkan insentif (upah) yang berhak diterima oleh seorang pekerja telah mereka atur dengan sedemikian pasti. Contoh kasus adalah pada bidang otomotif. Mengacu pada Ketentuan Umum Perpres Nomor 8 Tahun 2012 menyatakan bahwa sertifikasi kompetensi kerja adalah proses pemberian sertifikat kompetensi yang dilakukan secara sistematis dan objektif melalui uji kompetensi sesuai SKKNI, standar internasional, dan/atau standar khusus. Sertifikat kompetensi kerja adalah bukti tertulis yang diterbitkan oleh lembaga sertifikasi profesi terakreditasi yang menerangkan bahwa seseorang telah menguasai kompetensi kerja tertentu sesuai dengan SKKNI.

Dari uraian di atas, dapat ditafsirkan jika sertifikat kompetensi diterbitkan oleh lembaga sertifikasi profesi, dibutuhkan penguji yang tersertifikasi pula. Namun, untuk kasus dalam negeri kita terjadi dua model dalam satu jenis pengujian. Uji kompetensi yang dilakukan untuk menguji peserta didik kursus dan pelatihan dilakukan oleh Lembaga Sertifikasi Kompetensi (LSK) yang telah memiliki penguji yang terlatih dan memiliki sertifikat sebagai penguji. Berbeda dengan peserta didik di lembaga pendidikan formal (sekolah menengah kejuruan, SMK), uji kompetensi dilakukan secara mandiri oleh lembaga dengan partisipasi penguji dari DUDI. Pada penelusuran yang pernah penulis lakukan, ditemukan kasus bahwa penguji tidak memiliki sertifikat sebagai penguji kompetensi sesuai bidang keahliannnya, dan ada kesan lembaga pendidikan formal masih enggan melibatkan lembaga sertifikasi profesi/kompetensi dalam pengujian kompetensi peserta didiknya. Tanpa bermaksud meragukan kemampuan, selain secara teknis para penguji 
kompetensi yang berasal dari DUDI banyak yang belum memiliki sertifikat penguji sesuai bidang keahlian, ditemukan juga fakta sulit bagi mereka memahami keterkaitan antara SKKNI, SKL, dan naskah soal yang diturunkan saat pengujian. Artinya, jika kita ingin menyetarakan kualifikasi kita dengan negara lain, kualifikasi dan kompetensi lulusan pendidikan kita harus kita tingkatkan tanpa bisa ditawar-tawar lagi yang salah satu di antaranya adalah memastikan kualitas penguji.

Melalui penerapan program kurikulum mengacu KKNI, dapat dihasilkan capaian pembelajaran yang merupakan kemampuan yang diperoleh melalui internalisasi pengetahuan, sikap, keterampilan, kompetensi, dan akumulasi pengalaman kerja. Penyetaraan adalah proses penyandingan dan pengintegrasian capaian pembelajaran yang diperoleh melalui pendidikan, pelatihan kerja, dan pengalaman kerja sehingga dengan penerapan kurikulum mengacu KKNI melalui capaian pembelajaran, masalah yang selama ini ada, yakni orang mengukur kehebatan lembaga pendidikan tinggi dari aspek berapa banyak daya serap lulusannya di dunia kerja dapat terjawab. Jadi, dengan capaian pembelajaran dengan kemampuan yang dimiliki oleh peserta didik, masalah daya serap di dunia pekerjaan akan teratasi. Dengan kata lain, semakin banyak yang terserap di dunia pekerjaan, lembaga pendidikan tersebut dianggap sangat berkualitas.

Faktor keberhasilan dalam menerapkan kurikulum mengacu KKNI untuk mencapai peningkatan kualitas PTKIN tidak terlepas dari peran dan fungsi semua pihak unsur terkait antara lain unsur pimpinan yang ada di PTKIN, tenaga pendidik, tenaga kependidikan, dukungan pemerintah pusat dan dukungan pemerintah daerah, orang tua dan masyarakat bersama-sama bertanggung jawab terhadap penyelenggaraan pendidikan. Semua sistem yang ada mempunyai rasa memiliki dan berkepentingan menjadikan PTKIN yang berkualitas.

\section{Peningkatan Kualitas Pendidikan PTKIN}

Undang-Undang Nomor 12 Tahun 2012 Tentang Pendidikan Tinggi lahir pada akhir tahun 2012 disertai beragam tanggapan dari banyak kalangan, ada yang pro dan ada yang kontra. 
Seperti pendapat Taylor sebagaimana dikutip Sirozi (2004: 1) bahwa kebijakan sesungguhnya bersifat dinamis dan interaktif, dan hanya seperangkat suruhan atau niat. Kebijakan merupakan kompromi politik antara citra yang bertentangan mengenai bagaimana seharusnya perubahan pendidikan harus berjalan.

Di sisi lain, UU Dikti mengisyaratkan agar PTN menerapkan Pola Pengelolaan Keuangan Badan Layanan Umum (PPK-BLU) atau pilihan lainnya membentuk Badan Hukum. Melalui kebijakan ini, PTN harus mampu memobilisasi dana dari masyarakat, karena di lain hal subsidi dari pemerintah akan dikurangi. Akibatnya, PTN akan melakukan apa saja guna memperoleh dana dan yang paling dikhawatirkan akan membebankan kalangan tidak mampu (the have not) karena bisa saja PTN melakukan berbagai bentuk pungutan dengan dalih untuk peningkatan kualitas. Di lain pihak, perdebatan mengenai otonomi perguruan tinggi dalam hal kemandirian dalam mencari dana sebenarnya sudah jelas kelihatan semenjak diundangkannya UU BHP (saat ini sudah dibatalkan oleh Mahkhamah Konstitusi) yang sangat kentara bahwa UU Dikti dan UU BHP sesungguhnya ditengarai memiliki tujuan yang sama, yakni oleh sebagian kalangan dianggap mengkomersialisasikan pendidikan tinggi.

Kedua bentuk pilihan yang ditawarkan melalui UU Dikti tersebut menghadapkan PTKIN kepada sebuah bentuk kerisauan, di antaranya disebabkan jumlah peminat untuk memasuki PTKIN relatif terbatas, kemudian kemampuan untuk mengakses anggaran dari masyarakat juga sangat terbatas. Padahal, menjadi Perguruan Tinggi Berbadan Hukum tersebut identik dengan kemandirian dan otonomi kelembagaan pendidikan tinggi yang secara kelembagaan harus memperoleh anggaran secara mandiri. Memang ada aturan bahwa penarikan dana SPP dan sumbangan lain dari masyarakat tidak boleh melebihi $30 \%$ anggaran perguran tinggi, tetapi di dalam kerangka untuk meningkatkan generate income-nya, perguruan tinggi bisa saja berusaha dengan berbagai varian sehingga terjadi peningkatan masukan anggaran bagi perguran tinggi yang bersangkutan (Fattah, 2008: 1).

PTKIN merupakan salah satu pola perguruan tinggi yang berasaskan Islam, yang penyelenggaraannya berada di 
bawah naungan pemerintah. Berdasarkan fakta sejarah, PTKIN didirikan untuk memberikan pengajaran tinggi dan menjadi pusat untuk mengembangkan dan memperdalam ilmu pengetahuan tentang agama Islam. PTKIN bertujuan untuk memperbaiki dan memajukan pendidikan tenaga ahli agama Islam guna keperluan pemerintah dan masyarakat (Azra, 1999: 123). Pada perkembangan selanjutnya hingga saat ini, penyelenggaraan pendidikan tinggi di PTKIN mengambil concern pada pemberdayaan umat Islam Indonesia agar menjadi manusia yang terampil dalam menguasai ajaran dan nilai-nilai agama Islam serta mampu dalam hal penguasaan terhadap ilmu pengetahuan dan teknologi (Miswari, 2011: 38).

Salah satu problem pengembangan PTKIN terletak pada penyediaan sarana prasarana dan pengelolaan pendanaannya. PTKIN sebagai lembaga pendidikan berstatus negeri yang berada di bawah kewenangan pemerintah telah memiliki aturan dan pola pengelolaan dana secara baku, dengan kondisi dan situasi seperti itu, menjadikan PTKIN tidak akan banyak mengalami kemajuan sebagaimana yang diharapkan. Batas maksimal yang mampu diraih dengan kondisi keterbatasan dana seperti itu, maka dalam pencapaian tujuan hanyalah keberhasilan sebatas menjalankan perguruan tinggi. Padahal, seharusnya yang diharapkan dari pimpinan perguruan tinggi bukan sekadar melakukan peran itu, melainkan juga melakukan inovasi dan bahkan mereformulasi lembaganya secara terus menerus sesuai dengan dinamika masyarakat yang selalu berubah setiap saat.

PTKIN, terkait dengan pendanaan, selalu dihadapkan oleh pilihan yang amat rumit. Pada satu sisi dituntut dapat menyelenggarakan serta memajukan pendidikan tinggi secara berkelanjutan, sedang pada sisi lain selalu dibatasi dalam mengambil keputusan-keputusan yang strategis yang terkait dengan sumber dana. Padahal dengan mengacu pada pola dan bahkan besaran pendanaan yang diterima dari pemerintah selama ini tidak akan mencukupi. Jika dengan dana itu masih berjalan, sesungguhnya hanyalah sampai pada batas-batas minimal yang tidak mungkin diharapkan dapat mengalami peningkatan kualitas. 
Menurut Edward (2011: 192), banyak sumber kualitas yang mempengaruhi peningkatan kualitas pendidikan, misalnya sarana gedung yang bagus, pendidik yang terkemuka, nilai moral yang tinggi, hasil ujian yang memuaskan, spesialisasi atau kejuruan, dorongan orang tua, bisnis dan komunitas lokal, sumber daya yang melimpah, aplikasi teknologi mutakhir, kepemimpinan yang baik dan efektif, perhatian terhadap pelajaran anak didik, kurikulum yang memadai, atau juga kombinasi dari faktor-faktor tersebut.

Salah satu faktor penting yang berpengaruh pada kualitas pendidikan PTKIN adalah kurikulum yang memadai, di samping faktor tenaga pendidik, waktu belajar, manajemen, sarana fisik dan biaya pendidikan memberikan kontribusi yang berarti terhadap prestasi belajar. Sukmadinata (2006: 11) menyebutkan prinsipprinsip yang perlu dipegang dalam menerapkan program kualitas pendidikan di antaranya sebagai berikut.

a. Peningkatan kualitas pendidikan menuntut kepemimpinan professional dalam bidang pendidikan. Manajemen kualitas pendidikan merupakan alat yang dapat digunakan oleh para professional pendidikan dalam memperbaiki sistem pendidikan bangsa kita.

b. Kesulitan yang dihadapi para professional pendidikan adalah ketidak mampuan mereka dalam menghadapi "kegagalan sistem" yang mencegah mereka dari pengembangan atau penerapan cara atau proses baru untuk memperbaiki kualitas pendidikan yang ada.

c. Peningkatan kualitas pendidikan harus melakukan loncatan-loncatan. Norma dan kepercayaan lama harus diubah. Sekolah harus belajar bekerja sama dengan sumber-sumber yang terbatas. Para profesional pendidikan harus membantu para siswa dalam mengembangkan kemampuan-kemampuan yang dibutuhkan guna bersaing di dunia global.

d. Kualitas pendidikan dapat diperbaiki jika administrator, guru, staf, pengawas dan pimpinan kantor Diknas mengembangkan sikap yang terpusat pada 
kepemimpinan, team work, kerja sama, akuntabilitas, dan rekognisi.

e. Kunci utama peningkatan kualitas pendidikan adalah komitmen pada perubahan. Jika semua guru dan staf sekolah telah memiliki komitmen pada perubahan, pimpinan dapat dengan mudah mendorong mereka menemukan cara baru untuk memperbaiki efisiensi, produktivitas dan kualitas layanan pendidikan. Guru akan menggunakan pendekatan yang baru atau modelmodel mengajar, membimbing dan melatih dalam membantu perkembangan siswa. Demikian juga staf administrasi, ia akan menggunakan proses baru dalam menyusun biaya, menyelesaikan masalah, dan mengembangkan program baru.

f. Banyak profesional di bidang pendidikan yang kurang memiliki pengetahuan dan keahlian dalam menyiapkan para siswa memasuki pasar kerja yang bersifat global. Ketakutan terhadap perubahan atau takut melakukan perubahan akan mengakibatkan ketidaktahuan bagaimana mengatasi tuntutan baru.

g. Program peningkatan kualitas dalam bidang komersial tidak dapat dipakai secara langsung dalam pendidikan, tetapi membutuhkan penyesuaian-penyesuaian dan penyempurnaan. Budaya, lingkungan, dan proses kerja tiap organisasi berbeda. Para profesional pendidikan harus dibekali oleh program yang khusus dirancang untuk menunjang pendidikan.

h. Salah satu komponen kunci dalam program kualitas adalah sistem pengukuran. Dengan menggunakan sistem pengukuran memungkinkan para profesional pendidikan dapat memperlihatkan dan mendokumentasikan nilai tambah dari pelaksanaan program peningkatan kualitas pendidikan, baik terhadap siswa, orang tua, maupun masyarakat.

i. Masyarakat dan manajemen pendidikan harus menjauhkan diri dari kebiasaan menggunakan "program singkat”, peningkatan kualitas dapat dicapai melalui 
perubahan yang berkelanjutan tidak dengan programprogram singkat.

Selanjutnya, upaya peningkatan kualitas dan perluasan pendidikan membutuhkan sekurang-kurangnya tiga faktor utama, yaitu: (a) kecukupan sumber-sumber pendidikan dalam arti kualitas tenaga kependidikan, biaya dan sarana belajar; (b) kualitas proses belajar mengajar yang mendorong siswa belajar efektif; dan (c) kualitas keluaran dalam bentuk pengetahuan, sikap keterampilan, dan nilai-nilai (Fattah, 2008: 90). Jadi, kecukupan sumber, kualitas proses belajar mengajar, dan kualitas keluaran akan dapat terpenuhi jika dukungan biaya yang dibutuhkan untuk memenuhi sarana prasarana seperti penerapan kurikulum dapat disediakan, dan semua ini tentu saja memerlukan sumber daya pendidikan.

Kurikulum mengacu KKNI adalah kerangka penjenjangan kualifikasi kompetensi yang dapat menyandingkan, menyetarakan, dan mengintegrasikan antara bidang pendidikan dan bidang pelatihan kerja serta pengalaman kerja dalam rangka pemberian pengakuan kompetensi kerja sesuai dengan struktur pekerjaan di berbagai sektor. KKNI merupakan perwujudan kualitas dan jati diri bangsa Indonesia terkait dengan sistem pendidikan dan pelatihan nasional yang dimiliki Indonesia. Untuk menjaga keberlangsungan kualitas pendidikan pada PTKIN, adalah tugas dan peran Lembaga Penjaminan Mutu Pendidikan Islam pada Tingkat Perguruan Tinggi Islam (LPMPTKIN) yang ada pada institusi tersebut untuk mengawal kualitas pendidikan Islam PTKIN.

\section{Simpulan}

KKNI adalah kerangka penjenjangan kualifikasi kompetensi yang dapat menyandingkan, menyetarakan, dan mengintegrasikan antara bidang pendidikan dan bidang pelatihan kerja serta pengalaman kerja dalam rangka pemberian pengakuan kompetensi kerja sesuai dengan struktur pekerjaan di berbagai sektor. Penerapan KKNI melalui beberapa tahapan, yaitu: menyusun capaian pembelajaran, merumuskan merumuskan profil lulusan program studi, perumusan standar kompetensi 
lulusan learning outcomes, perumusan capaian pembelajaran program studi (program learning outcomes/PLO), perumusan capaian pembelajaran mata kuliah (course leaning outcomes/ CLO), menemukenali konsep kunci dan kata kunci pada capaian pembelajaran mata kuliah, pengembangan RPKPS (Rencana Program dan Kegiatan Pembelajaran Semester).

Peningkatan kualitas PTKIN dipengaruhi oleh penerapan/ penerapan kurikulum KKNI melalui tiga faktor utama, yaitu: (1) kecukupan sumber-sumber pendidikan dalam arti kualitas tenaga kependidikan, biaya, dan sarana belajar; (2) kualitas proses belajar mengajar yang mendorong siswa belajar efektif; dan (3) kualitas keluaran dalam bentuk pengetahuan, dan sikap keterampilan.

Berdasarkan temuan yang ada, dapat direkomendasikan kepada seluruh PTKIN hendaknya segera menerapkan kurikulum mengacu KKNI dan kepada pemerintah hendaknya mengalokasikan dana yang imbang kepada PTKIN untuk penerapan kurikulum mengacu KKNI dalam upaya peningkatan kualitas pendidikan PTKIN. 


\section{DAFTAR PUSTAKA}

Adams, Don. 1993. Defining Educational Quality dalam Improving Educational Quality Project. Arlington: Institute for International Research.

Arcaro, Jerome S. 2005. Pendidikan Mengacu Kualitas: PrinsipPrinsip Perumusan dan Tata Langkah Penerapan. Yogyakarta: Pustaka Pelajar.

Azra, Azyumardi. 1999. Esei-Esei Intelektual Muslim dan Pendidikan Islam. Jakarta: Logos Wacana Ilmu.

Effendi, Sofian. 2007. "Menghadapi Liberalisasi Pendidikan Tinggi”, Seputar Indonesia, 13 Maret 2007.

Fattah, Nanang. 2008. "Pembiayaan Pendidikan: Landasan Teori dan Studi Empiris", Jurnal Pendidikan Dasar 1.

Ferguson, Marjorie. 2002. The Mythology About Globalization. London: Sage Publications.

Hedwig, Rinda. 2007. Sistem Penjaminan Kualitas di Perguruan Tinggi Monitoring Dan Evaluasi Internal. Yogyakarta: Graha Ilmu.

al-Jabburi, Imran Jasim dan Hamzah Hasyim as-Sulthani. 2013. Al-Manahij wa Thara'iq Tadris al-Lughah al-Arabiyyah. 'Amman: Muassasah Dar ash-Shadiq ats-Tsaqafiyyah.

Miswari. 2011. "Peranan TQM Terhadap Mutu Lembaga Pendidikan Tinggi Islam", Jurnal Pendidikan Islam 1.

Pelikan, Jaroslav. 1992. The Idea of The University: a Reaxamination. New Haven: Yale University Press.

Peraturan Presiden Nomor 8 Tahun 2012 Tentang Kerangka Kualifikasi Nasional Indonesia (KKNI).

Sallies, Edward. 2006. Total Quality Management In Education. Yogyakarta: IRCiSoD.

Setiawan, Deny. 2016. Seminar Nasional Pendidikan Ilmu-Ilmu Sosial Membentuk Karakter Bangsa Dalam Rangka Daya Saing Global. Makassar: UNM. 
Sirozi, Muhammad. 2004. Politik Kebijakan Pendidikan di Indonesia: Peran Tokoh-Tokoh Islam dalam Penyusunan UU No. 2/1989. Jakarta: INIS.

Sukmadinata, Nana Syaodih. 2006. Pengendalian Mutu Pendidikan Sekolah Menengah. Bandung: PT Refika Aditama.

Suwito, dkk. Laporan Review Kurikulum Mengacu KKNI dan SNPT. Purwokerto: IAIN Purwokerto.

Suwadi. 2016. "Pengembangan Kurikulum Pendidikan Agama Islam pada Pendidikan Tinggi Mengacu KKNI-SNPT Berparadigma Integrasi-Interkoneksi di Program Studi PAI FITK UIN Sunan Kalijaga Yogyakarta", Jurnal Pendidikan Agama Islam 2.

Syam, Nur. 2014. Dari Bilik Birokrasi: Esai Agama, Pendidikan, dan Birokrasi. Bekasi: PT Senama Sejahtera Utama. 